\title{
SERUM VITAMIN D LEVEL IN CHILDREN WITH ATOPIC DERMATITIS AND ITS RELATIONSHIP TO THE SEVERITY OF THE DISEASE.
}

\author{
Samia Ali Ibrahim* and Aza Mostafa**. \\ Departments of Dermatology* and Clinical Pathology**,Faculty of Medicine, Zagazig University.
}

\section{ABSTRACT}

Background: Atopic Dermatitis (AD) is an allergic inflammatory skin disease with significant cost and morbidity to the patients and their families. Vitamin D has been suggested to have a role in the pathogenesis of allergic disorders, including AD. Objective: The aim of the study was to measure the serum levels of vitamin D in the form of 25hydroxy vitamin $\mathrm{D}$ in children with $\mathrm{AD}$ and to correlate them with the severity of the disease. Patients and methods: The study included forty children with the clinical diagnosis of AD. Using Scoring Atopic Dermatitis (SCORAD) index, the patients were divided into three groups; mild (SCORAD index $<25)$, moderate $(25-50)$ and severe (>50). Vitamin D levels were measured in the sera of the patients using Chemiluminescent method. Specific IgE to Staphylococcus aureus (S.aureus) Enterotoxins (A, B and C) and Malessazia furfur (M.furfur) in the sera of the patients was also measured using Immunocap system. Results: AD was mild in 16 patients, moderate in 14 patients and severe in 10 patients. The mean SCORAD index \pm SD was $14.01 \pm 5.6,38.71 \pm 7.8$ and $60.8 \pm 7.5$ in the three groups respectively. Mean vitamin D levels \pm SD in the sera of the patients in $\mathrm{ng} \mathrm{ml}^{-1}$ were sufficient (36.3 \pm 13.06$)$ in 15 patients, insufficient $(26.6 \pm 7.4)$ in 16 patients and deficient $(19.8 \pm 5.2)$ in 9 patients. There was a significant inverse correlation between the serum levels of vitamin $\mathrm{D}$ and the severity of $\mathrm{AD}(\mathrm{r}=-0.48, \mathrm{P}=0.003)$. There was also a significant difference between the mean serum level of vitamin $\mathrm{D}$ in mild and moderate $\mathrm{AD}$ $(\mathrm{P}<0.05)$, and mild and severe $\mathrm{AD}(\mathrm{P}<0.05)$. Specific IgE to S.aureus enterotoxin and to M.furfur antigens was more in patients with severe $\mathrm{AD}$ who had deficient levels of vitamin $\mathrm{D}$ than in those with mild or moderate disease. Conclusion: Vitamin D level is inversely related to the severity of the disease in AD patients and consequently it may have a role in its treatment.

\section{INTRODUCTION}

A topic dermatitis (AD) is an allergic chronic inflammatory type of eczema. It is an important skin condition with significant cost and morbidity to the patients and their families. The underlying cause of $\mathrm{AD}$ has not been established, however several studies have shown initial epidermal barrier defect with subsequent immune activation as the underlying mechanism of the disease ${ }^{(\mathbf{1})}$.

Vitamin D insufficiency data is expanding to include evidence of its role in asthma, allergic disorders and $\mathrm{AD}{ }^{(2)}$. In addition to its well documented relationship with rickets and bone metabolism, vitamin D is now recognized as immunomodulator $^{(2)}$. However, conflicting data exist with respect to the role of vitamin $\mathrm{D}$ in the pathogenesis of allergic disorders ${ }^{(2)}$.

The prevalence of $\mathrm{AD}$ and allergic rhinitis was higher in subjects who received vitamin D supplements in infancy ${ }^{(3)}$. In another prospective study of 4000 infants, in whom 98\% were supplemented with vitamin A and D (400 I U/day of vitamin D), in either a water soluble or peanut oil form, showed that infants who received water soluble supplements had a greater risk of asthma, food sensitivity and aeroallergen sensitization at the age of 4 years than infants given peanut oil form ${ }^{(4)}$.
Back et al. have demonstrated that a higher vitamin $\mathrm{D}$ intake during the first year of life was significantly correlated to atopic manifestations at 6 years of age ${ }^{(5)}$. On the other hand, it has been shown that infants born to mothers with low vitamin D intake ${ }^{(6)}$ or low fish consumption (7) during pregnancy presented an increased prevalence of atopic manifestations in their babies. A greater risk of $\mathrm{AD}$ has been observed in infants born in autumn and winter as compared to those born in spring and summer ${ }^{(8)}$. In 2012, Amestejani et al. reported beneficial effects on $\mathrm{AD}$ from oral supplementation with vitamin $D$ in a small sample size of children with winter related worsening of $\mathrm{AD}^{(9)}$.

Vitamin $\mathrm{D}$ has been demonstrated to have an effect on the integrity of the permeability barrier of the epidermis, together with its role in maturation and activity of lymphoid tissues involved in the development and control of allergic manifestations ${ }^{(\mathbf{1})}$.

The aim of this study was to evaluate the possible role of vitamin $D$ in the pathogenesis of $\mathrm{AD}$ by measuring the serum level of vitamin $\mathrm{D}$ in the form of 25 hydroxyvitamin $D$ and correlating it with the severity of the disease in children with AD.

Patients and Methods: Forty patients with AD, their ages ranged from 1-12 years old, were 
included in this study. They were chosen from patients attending the outpatient clinics of Dermatology and Pediatric Departments of Zagazig University Hospitals, in the period from June 2011-June 2012. Only children who were not taking vitamin D supplements for at least 6 months and those who had not received topical steroids in the previous 4 weeks were included in this study. Patients who received calcineurin inhibitors (in the last 2 weeks) or any systemic anti-inflammatory treatments (in the previous last month) were also excluded from the study.

An informed consent was taken from the parents according to the local Hospital's Ethics.

Methods: All the patients were subjected to complete medical history, general medical and dermatological examinations; $\mathrm{AD}$ was diagnosed according to the U.K. Working Party's diagnostic criteria for AD. $111^{(\mathbf{1 0})}$. The severity of the disease was evaluated using SCORAD index as mild $<25$, moderated 25-50 and severe $>50$ as defined in previous studies ${ }^{(11)}$. A blood sample was taken from every patient and the serum was separated. Vitamin D levels in the serum were measured once using chemiluminescent method (LIAISon 25-OH vitamin D Total; Driason, Saluggia, Italy). Values were used as a continuous variable and vitamin $\mathrm{D}$ amounts were also categorized, in a descriptive analysis as follows: sufficient (3040ng $\mathrm{mL}^{-1}$ ), insufficient (20-30 $\mathrm{ng} \mathrm{mL} \mathrm{m}^{-1}$ ) and deficient $\left(<20 \mathrm{ng} \mathrm{mL}^{-1}\right)^{(\mathbf{1 2})}$.

Specific IgE (SIgE) to S.aureus Enterotoxin (SE) A, SEB and SEC and SIgE to M.furfur were assayed by Immuno Cap system (phadia, Milan, Italy)). Specific IgE concentration 0.35 $\mathrm{Ku} \mathrm{L}^{-1}$ ) were considered to be positive ${ }^{(\mathbf{1 3})}$.

\section{Statistical methods:}

Comparison of vitamin $\mathrm{D}$ levels among $\mathrm{AD}$ patients with different SCORAD index was performed by ANOVA, $\mathrm{p}<0.05$ was considered significant. The association between SCORAD index and vitamin $\mathrm{D}$ value was performed using a Pearson's correlation test.

Results: This study conducted on forty $\mathrm{AD}$ children. Their ages ranged from 1-12 years. They were 18 girls and 22 boys.

The mean SCORAD value \pm SD were $14.01 \pm 5.6$, $38.71 \pm 7.8$ and $60.8 \pm 7.5$ in mild $(<25)$, moderate (25-50) and severe (>50) AD respectively, as shown in table (1).

\begin{tabular}{llll}
\hline & $\begin{array}{l}\text { Mild } \\
\mathrm{AD}<25\end{array}$ & $\begin{array}{l}\text { Moderate } \\
\text { AD 25-50 }\end{array}$ & $\begin{array}{l}\text { Severe } \\
\text { AD >50 }\end{array}$ \\
\hline $\begin{array}{l}\text { No.of } \\
\text { patients }\end{array}$ & 16 & 14 & 10 \\
\hline $\begin{array}{l}\text { Percent of } \\
\text { patients }\end{array}$ & 40 & 35 & 25 \\
\hline $\begin{array}{l}\text { Mean } \\
\begin{array}{l}\text { SCORAD } \\
\pm \text { SD }\end{array}\end{array}$ & $14.01 \pm 5.6$ & $38.71 \pm 7.8$ & $60.8 \pm 7.5$ \\
\hline
\end{tabular}

Table (1): The mean SCORAD value in the studied patients.

Serum concentrations of 25 hydroxy vitamin D were found to be sufficient $\left(30-40 \mathrm{ng} \mathrm{ml}^{-1}\right)$, insufficient (20-30 $\left.\mathrm{ng} \mathrm{ml}^{-1}\right)$ and deficient $(<20$

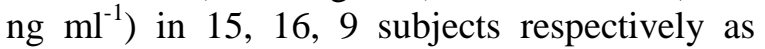
shown in table 2 .

\begin{tabular}{llll}
\hline & $\begin{array}{l}\text { Sufficient } \\
(30-40)\end{array}$ & $\begin{array}{l}\text { Insufficient } \\
(20-30)\end{array}$ & $\begin{array}{l}\text { Deficient } \\
(<20)\end{array}$ \\
\hline $\begin{array}{l}\text { No.of } \\
\text { patients }\end{array}$ & 15 & 16 & 9 \\
\hline Percent. & 37.75 & 40 & 22.25 \\
\hline
\end{tabular}

Table (2): Serum concentrations of 25 hydroxy Vit $\mathrm{D}$ in $\mathrm{AD}$ children in $\mathrm{ng} \mathrm{ml}^{-1}$.

Mean serum level \pm SD of hydroxy vitamin $D$ in $\mathrm{ng} \mathrm{ml}^{-1}$ in mild $\mathrm{AD}$ was $36.3 \pm 13.06$, in moderate $\mathrm{AD}$ was $26.6 \pm 7.4$ and in severe $\mathrm{AD}$ was $19.8 \pm 5.2$ as shown in figure (1).

The highest serum levels of 25 hydroxy vitamin $\mathrm{D}$ were found in $\mathrm{AD}$ patients with mild SCORAD. There was a significant statistical difference between the mean serum vitamin $\mathrm{D}$ levels in mild and severe AD patients ( $\mathrm{P}$ value < $0.05)$. The statistical difference in the serum levels of hydroxyl vitamin D in patients with mild and moderate $\mathrm{AD}$ was also significant $(\mathrm{P}<0.05)$, as shown in Figure (1). 


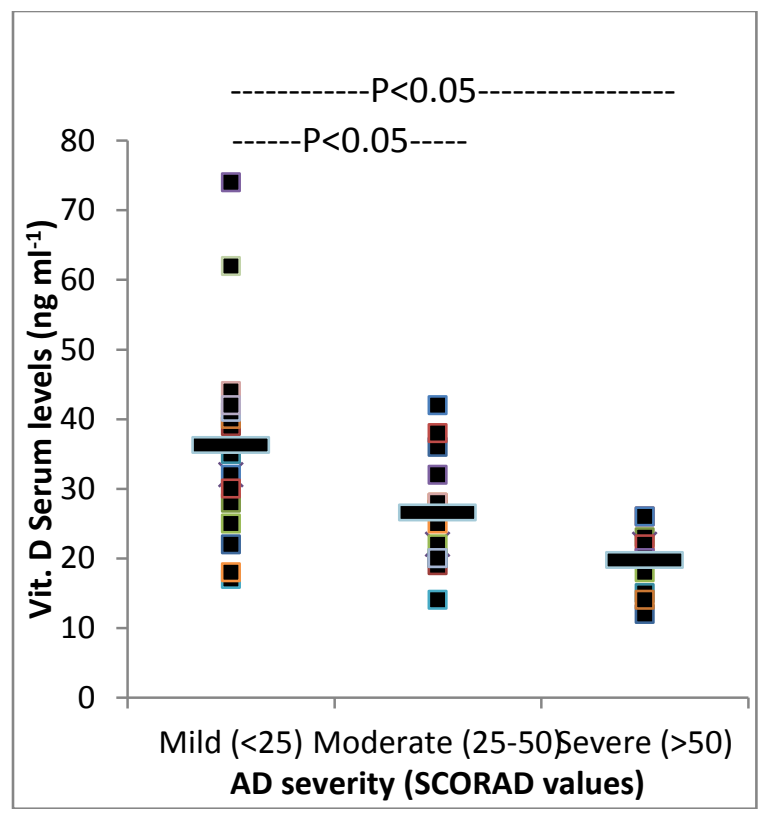

Figure 1: Serum vitamin $D$ levels in relation to different threshold values of atopic dermatitis (AD) severity. Horizontal lines indicate mean values.

There was a significant inverse relation between serum vitamin $\mathrm{D}$ levels and individual SCORAD index $(r=-0.48, P=0.003)$ as shown in Figure 2.

Figure 2: Correlation between serum vitamin $D$ levels and the individual SCORAD values.

Allergic sensitization to $S$. aureus superantigens and M.furfur in patients with mild, moderate and severe $\mathrm{AD}$ showed a direction towards an increased number of patients with specific $\operatorname{IgE}$ to $S$. aureus enterotoxins and M.furfur in the group of patients with severe $\mathrm{AD}$ as shown in table 3 .

Table (3): Showing specific antigens to S.aureus enterotoxins and to M.furfur in children with mild, moderate and severe AD.

\begin{tabular}{|c|c|c|c|c|c|}
\hline & $\begin{array}{l}\text { No.of } \\
\text { patients }\end{array}$ & $\begin{array}{l}\text { SEA } \\
\text { IgE+ } \\
\mathrm{N}(\%)\end{array}$ & $\begin{array}{l}\text { SEB } \\
\text { IgE+ } \\
\mathrm{N}(\%)\end{array}$ & $\begin{array}{l}\text { SEC } \\
\text { IgE+ } \\
\mathrm{N}(\%)\end{array}$ & $\begin{array}{l}\text { MF } \\
\text { IgE+ } \\
\mathrm{N}(\%)\end{array}$ \\
\hline Mild AD & 16 & $\begin{array}{l}5 \\
(31 \%)\end{array}$ & $\begin{array}{l}5 \\
(31 \%)\end{array}$ & $\begin{array}{l}6 \\
(37.5 \%)\end{array}$ & $\begin{array}{l}5 \\
(31 \%)\end{array}$ \\
\hline $\begin{array}{l}\text { Moderate } \\
\mathrm{AD}\end{array}$ & 14 & $\begin{array}{l}5 \\
(35.7 \%)\end{array}$ & $\begin{array}{l}4 \\
(28.5 \%)\end{array}$ & $\begin{array}{l}5 \\
(35.7 \%)\end{array}$ & $\begin{array}{l}6 \\
(42 \%)\end{array}$ \\
\hline Severe AD & 10 & $\begin{array}{l}4 \\
(40 \%)\end{array}$ & $\begin{array}{l}5 \\
(50 \%)\end{array}$ & $\begin{array}{l}5 \\
(50 \%)\end{array}$ & $\begin{array}{l}7 \\
(70 \%)\end{array}$ \\
\hline
\end{tabular}

SE: S.aureus enterotoxin A, B , C. MF: M.furfur.

\section{DISCUSSION}

Dysfunctions of both epidermal barrier and immune system represent the main pathogenic mechanisms of atopic dermatitis and patients with this disease can have defects in both permeability and antimicrobial barriers of the stratum corneum (SC) ${ }^{(14)}$. The permeability barrier consists of hydrophobic lipids that percolate the environment surrounding SC and prevent water loss into the extracellular environment ${ }^{(14)}$.

Overactivity of the enzymes, serine proteases, secondary to genetic defects such as defects of the gene encoding filaggrin, and environmental stimuli like alkaline soaps promotes reduction of hydration and extracellular lipids in SC, introduction of antigens and promotion of inflammation ${ }^{(\mathbf{1 4})}$. Loss of function mutation in the gene encoding filaggrin are associated with $\mathrm{AD}^{(15)}$.

The barrier dysfunction also involved antimicrobial barrier. Antimicrobial peptides (AMPS) represent an important part in this barrier, as a first line defense against infection. cathelicidin is one of the most important AMPs and is expressed in keratinocytes and mast cells ${ }^{(\mathbf{1 6})}$. Its deficiency is known to be associated with $\mathrm{AD}^{(\mathbf{1 7 )}}$ as it plays a role in immune system signaling that enhances antimicrobial activity against S.aureus and $M$.furfur.

Vitamin D data expanded to involve its roles in the pathogenesis of allergic disorders including $\mathrm{AD}^{(2)}$, so we studied in this work the relation between Vitamin $\mathrm{D}$ serum levels and atopic manifestations in $\mathrm{AD}$ of children. We found an inverse relation between the serum levels of vitamin $\mathrm{D}$ in children with $\mathrm{AD}$ and the severity of the disease as evaluated by SCORAD 
index $(\mathrm{p}=0.003, \mathrm{r}=-0.48)$. There was also a significant difference between the mean vitamin $\mathrm{D}$ serum levels in patients with mild $\mathrm{AD}$ and those with moderate $(p<0.05)$ and severe $(\mathrm{p}<0.05) \mathrm{AD}$. This is in agreement with the previous studies that linked vitamin $\mathrm{D}$ deficiency to the prevalence of $\mathrm{AD}^{(6,8)}$. In contrary, Back et al have shown a direct correlation between vitamin $\mathrm{D}$ levels and severity of the disease in $\mathrm{AD}$ patients ${ }^{(5)}$. We can explain our results by the fact that the enzymes responsible for the conversion of vitamin $\mathrm{D}$ into the active form of the vitamin are found in the keratinocytes $^{(\mathbf{1 8})}$. Vitamin $\mathrm{D}$ has a role in the permeability barrier in the epidermis. Its beneficial effect on the permeability barrier was evidenced by the presence of the lower levels of multiple proteins in the null mice compared to the wild type controls. These proteins (including filaggrin) are necessary for formation of the $\mathrm{SC}^{(19)}$. In the same study, Bikle and his colleagues measured the expression of 25hydroxyvitamin D-1 $\alpha$-hydroxylase in the null mice (this enzyme is essential for the initial hydroxylation of vitamin $\mathrm{D}$ to 25 hydroxyvitamin D), following tape disruption, null mice has significantly delayed barrier recovery ${ }^{(19)}$

Vitamin D in addition plays a role in the antimicrobial barrier of the skin as it has a role in the immune system signaling. It has been shown to have a significant role in cathelicidin expression in the $\operatorname{skin}^{(16)}$, that enhances antimicrobial activity against $S$. aureus and M.furfur. Wang and his group demonstrated that promoters of cathelicidin and beta-2 defensin (AMP) genes consensus vitamin D response element and that 1,25 dihydroxy vitamin $\mathrm{D}$ promotes antimicrobial gene expression ${ }^{(20)}$. It has been proposed that skin infection and injury leads to activation of CYP27B1 (the enzyme responsible for the conversion of vitamin $\mathrm{D}$ into the active form) and up-regulated VDR (vitamin $\mathrm{D}$ receptors) expression which in turn leads to increased production of activated vitamin $\mathrm{D}$ and AMPS $^{(21)}$

Vitamin D decreases synthesis of IL-1, IL-6 and RANTES (regulated and normal T cell expressed and secreted) that decreases inflammation of the epidermal keratinocytes ${ }^{(\mathbf{2 2})}$.
VDRs are located on macrophages and dendretic cells (DCS) as is CYP27B1. 1, 25 dihydroxy vitamin $\mathrm{D}$ has been shown to have inhibitory effects on the differentiation of $\mathrm{DCS}^{(\mathbf{2 3})}$. In vitro treatment of DCS with vitamin D leads to decrease in IL-12 and enhanced IL10. These cytokines effects along with the inhibitory effects on DCS maturation promote tolerogenic properties and suppressor $\mathrm{T}$ cells induction $^{(22)}$. Vitamin $\mathrm{D}$ induced tolerogenic DCS and increased T regulatory cells in mice ${ }^{(24)}$.

In this study, an increased prevalence of patients who were positive for the presence of Specific IgE either to S.aureus or M.furfur or both was found in patients with severe AD $(40 \%, 50 \%, 50 \%$ and $70 \%$ of patients were positive to presence of SIgE to SEA,B,Cand M.furfur respectively) than those in patients with mild $(31 \%, 31 \%, 37.5 \%$ and $31 \%)$ and moderate $(35.7 \%, 28.5 \%, 35.7 \%$ and $42 \%)$ AD. Serum vitamin $\mathrm{D}$ was also at its lowest levels in patients with severe $\operatorname{AD}\left(19.8 \pm 5.2 \mathrm{ng} \mathrm{ml}^{-1}\right)$. This can be explained by the decreased expression of AMPS that represent an important part in the antimicrobial barrier of the skin against bacteria and fungi in patients with low vitamin D levels $(16,21)$

\section{CONCLUSION AND RECOMMENDATION:}

Vitamin D serum level is inversely correlated with the disease severity in children with AD. This indicates that Vitamin D may have a role in the pathogenesis of $\mathrm{AD}$ and consequently a beneficial effect in the treatment and prevention of the disease, which needs further research.

\section{REFERENCES}

1-Mutgi K and Tag K: Update on the role of systemic Vit $\mathrm{D}$ in atopic dermatitis. J. Pediatric Dermatology 2012; Sep.

2-Searing DA and Leung DYM: Vitamin D in atopic dermatitis, asthma and allergic diseases.Immunol Allergy Clin North Amer 2010; 30(3):397-409.

3-Hypponen E, Sovio U, Wjst M et al: Infant vitamin $\mathrm{D}$ supplementation and allergic conditions in adult food: Northern Finland Birth Cohort 1960. Ann Ny Acad Sci 2004; 1037:84-95.

4-Kull I, Bergstrom A, Melen E et al: Early life supplementation of vitamin A and D in water soluble form or peanut oil and allergic diseases during childhood. J Allergy Clin Immunol 2006; 118(6): 1299-304.

5-Back O, Blomquist HK, Hernell O et al: Does vitamin $\mathrm{D}$ intake during infancy promote the 
development of atopic allergy. Acta Derm Venereol 2009; 89:28-32.

6-Miyake Y, Sasaki S, Tanaka K et al: Maternal diary food, calcium and vitamin D intake in pregnancy and wheeze and eczema in infants. Eur Respir J 2010; 35:1228-34.

7-Willer SM, Devereux G, Craig LC et al: Food consumption during pregnancy and asthma, respiratory and atopic symptoms in 5-years old children. Thorax 2007; 62:773-9.

8-Kuzame K and Kusu M: Before-birth climatologic data may play a role in the development of allergies in infants. Pediatr Allergy Immunol 2007; 18:281-7.

9-Amestejani M, Salehi BS, Vasigh M et al: Vitamin $\mathrm{D}$ supplementation in the treatment of atopic dermatitis: A clinical trial study. J Drugs Dermatol 2012; 11(3):327-30.

10-Williams HC, Burney PGJ, Pembroke AC et al: The U.K. Working Party's diagnostic criteria for atopic dermatitis. 111. Independent hospital validation. Br J Dermatol 1994; 131:406-16.

11-Oranji AP, Glazenburg EJ, Wolkerwstorfer A et al: Practical issues on interpretation of scoring atopic dermatitis: The SCORAD index, objective SCORAD and the three item severity score. Br J Dermatol 2007; 157:645-8.

12-Holik MF: Vitamin D deficiency. N Eng J Med 2007; 357:266-81.

13-Peroni DG, Piacentini GL, Cametti E et al: Correlation between serum 25-hydroxy vitamin D levels and severity of atopic dermatitis. $\mathrm{Br} \mathbf{J}$ Dermatol 2011; 164:1078-82.

14-Elias PM, Hatano Y, Williams ML et al: Basis for barrier abnormality in atopic dermatitis: Outsideinside-outside pathogenic mechanisms. J Allergy Clin Immunol 2008; 121(6):1337-43.

15-O'Regan GM, Sandilands A, Mclean WH et al: Filaggrin in atopic dermatitis. J Allergy Clin Immunol 2008;122(4):689-93.

16-Schauber J and Gallo RL: anti- microbial peptides and the skin defense system. J Allergy Clin Immunol 2008;122(2):261-6.

17-Ong PY, Ohtak T, Brandt C et al: Endogenous anti-microbial peptides and skin infection in atopic dermatitis. N Eng J Med 2002;347(15):1151-60.

18-Zhang JZ, Maruyama K, Ono I et al: Regulatory effects of 1,25- dihydroxy vitamin $\mathrm{D}_{3}$ and a novel vitamin $\mathrm{D}_{3}$ analogue MC903 on secretion of IL-1 $\alpha$ and IL-8 by normal human keratinocytes and human squamas cell carcinoma cell line (HSC-1). J Dermatol Sci 1994;7(1):24-31.

19-Bikle DD, Pillai S, Gee E et al: 1,25-dihydroxy vitamin $\mathrm{D}$ production in human keratinocytes by interferon gamma. Endocrinology $1989 ; 124(2): 655-60$
20-Wang TT, Nestel FP, Bourdeau M et al: Cutting edge: 1,25-dihydroxy vitamin $\mathrm{D}_{3}$ is a direct inducer of anti-microbial peptide gene expression. J Immunol 2004; 173(5):1909-12.

21-Liu PT, Stenger S, Li H et al: Toll-like receptor triggering of vitamin $\mathrm{D}$ mediated anti-microbial response. Science 2006;311(5768):1770-3.

22-Fukuoka M, Ogino Y, Sato $\mathrm{H}$ et al: RANTES expression in psoriatic skin and upregulation of RANTES and IL-8 production in cultured epidermal keratinocytes by active vitamin D(Tacalcitol). Br J Dermatol 1998;138(1):63-70.

23-Adorini L, Penna G, Giarratana N et al: Dendretic cells as key targets for immunomodulation by vitamin D receptor ligands. J Steroid Biochem Mol Biol 2004; 90(5):437-41.

24-Gregori S, Casorati M, Amuchastegui S et al: Regulatory T cells induced 1 $\alpha, 25$-dihydroxy vitamin $\mathrm{D}_{3}$ and mycophenolate motefil treatment mediate transplantation tolerance. J Immunol 2001;167(4): 1945-53 


\section{العلاقة بين مستوى قيتامين د فى المصل وشدة المرض فى الأطفال المصابين بحساسية الجلد الوراثية}

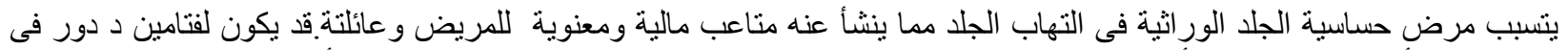

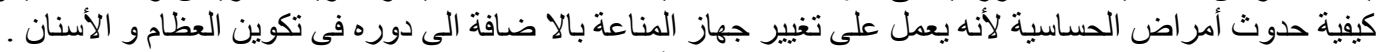

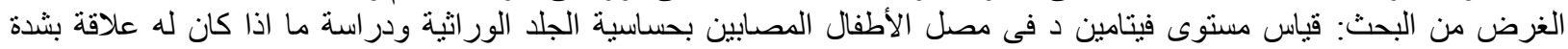
المرض.

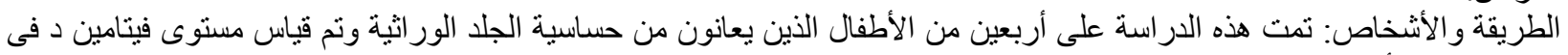

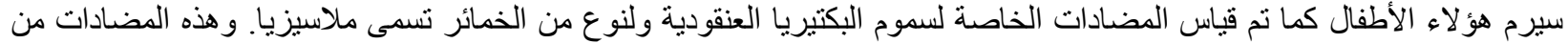
الفصيلة هو الاع. النتيجة: يوجد علاقة عكسية بين مستوى فيتامين د وشدة المرض في الأطفال المصابين بحساسية الجلد الور اثية كما وجد ان المضادات

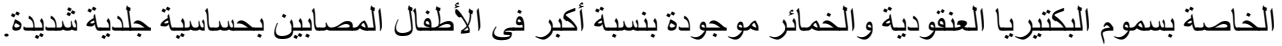

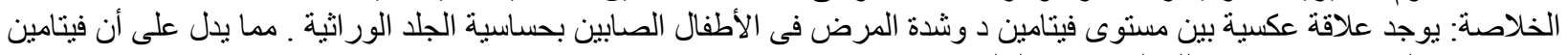

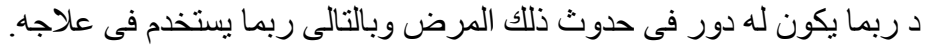

